\title{
ROUTLEDGE HANDBOOK OF JAPANESE SOCIOLINGUISTICS
}

Presenting new approaches and results previously inaccessible in English, the Routledge Handbook of Japanese Sociolinguistics provides an insight into the language and society of contemporary Japan from a fresh perspective.

While it was once believed that Japan was a linguistically homogenous country, research over the past two decades has shown Japan to be a multilingual and sociolinguistically diversifying country. Building on this approach, the contributors to this handbook take this further, combining Japanese and western approaches alike and producing research which is relevant to twenty-first century societies. Organised into five parts, the sections covered include:

- The languages and language varieties of Japan.

- The multilingual ecology.

- Variation, style and interaction.

- Language problems and language planning.

- Research overviews.

With contributions from across the field of Japanese sociolinguistics, this handbook will prove very useful for students and scholars of Japanese studies, as well as sociolinguists more generally.

Patrick Heinrich is Professor at the Department of Asian and African Studies at Ca' Foscari University in Venice, Italy, where he teaches Japanese and Ryukyuan sociolinguistics. His recent publications include Urban Sociolinguistics (Routledge, 2017) and The Making of Monolingual Japan (2012).

Yumiko Ohara is Professor in the College of Hawaiian Language at University of Hawai i at Hilo, USA, where she teaches pragmatics and linguistics of endangered languages. Her publications include Various Approaches to Japanese Discourse (2007). 


\section{ROUTLEDGE HANDBOOK OF JAPANESE SOCIOLINGUISTICS}

Edited by Patrick Heinrich and Yumiko Ohara 
First published 2019

by Routledge

2 Park Square, Milton Park, Abingdon, Oxon OX14 4RN

and by Routledge

52 Vanderbilt Avenue, New York, NY 10017

Routledge is an imprint of the Taylor \& Francis Group, an informa business

(C) 2019 selection and editorial matter, Patrick Heinrich and Yumiko Ohara; individual chapters, the contributors

The right of Patrick Heinrich and Yumiko Ohara to be identified as the authors of the editorial material, and of the authors for their individual chapters, has been asserted in accordance with sections 77 and 78 of the Copyright, Designs and Patents Act 1988.

All rights reserved. No part of this book may be reprinted or reproduced or utilised in any form or by any electronic, mechanical, or other means, now known or hereafter invented, including photocopying and recording, or in any information storage or retrieval system, without permission in writing from the publishers.

Trademark notice: Product or corporate names may be trademarks or registered trademarks, and are used only for identification and explanation without intent to infringe.

British Library Cataloguing-in-Publication Data

A catalogue record for this book is available from the British Library

Library of Congress Cataloging-in-Publication Data

A catalog record has been requested for this book

ISBN: 978-0-415-79027-7 (hbk)

ISBN: 978-1-315-21337-8 (ebk)

Typeset in Bembo

by Newgen Publishing UK 
For Katsue Akiba-Reynolds and Orie Endo, and in memory of Jirí Václav Neustupný (1933-2015) 


\section{CONTENTS}

List of figures

List of tables

List of contributors

xii

Acknowledgements

xviii

Conventions

$\mathrm{xx}$

\section{PART I}

The languages and language varieties of Japan

1 Ainu language and Ainu speakers

Mika Fukazawa

2 Ryukyuan sociolinguistics

Masahide Ishihara, Katsuyuki Miyahira, Gijs van der Lubbe and Patrick Heinrich

3 Ryukyu-substrate Japanese: Contact effects on the replacing language Mark Anderson

4 Japanese dialects Shinji Sanada

5 Koine and koineization

Shin Abe

6 Language and migration in Japan Ruriko Otomo 
7 English in Japan

Ryuko Kubota

\section{PART II}

The multilingual ecology

8 Metroethnicity: From standardized identities to language aesthetics

John C. Maher

9 Metrolingualism in transitional Japan Emi Otsuji

10 Linguistic landscape

Peter Backhaus

11 Bilingualism and bilingual education in Japan

Sachiyo Fujita-Round

12 Japan as a multilingual society

Hiroshi Shoji

\section{PART III}

\section{Variation, style and interaction}

13 Language variation and change

Kazuko Matsumoto

14 Code switching, language crossing and mediatized translinguistic practices

Rika Yamashita

15 Language and social relations

Zi Wang

16 Politeness

Yasuko Obana

17 Impoliteness

Yukiko Nishimura

18 Gendered speech

Yumiko Ohara 


\section{PART IV}

Language problems and language planning

19 Language policy and planning

Ruriko Otomo

20 Script and orthography problems

Hidenori Masiko

21 Literacy and illiteracy

Takeshi Nakashima

22 Japanese language spread in the colonies and occupied territories

Toshiaki Yasuda

23 Ainu language shift

Takayuki Okazaki

24 Language shift in the Ryukyu Islands

Mark Anderson

25 Language rights

Goro Christoph Kimura

\section{PART V}

Research overviews

26 Language life (gengo seikatsu)

Patrick Heinrich

27 The study of Japanese language speakers

Riikka Länsisalmi

28 Studies of Ryukyu-substrate Japanese

Mark Anderson

Index 


\section{FIGURES}

1.1 Division of Ainu dialects

1.2 Distribution of place names with koyka or koypok

1.3 Dialect division according to the Ainu Dialect Atlas

2.1 Mixed language school sign made by an elementary school student 31

4.1 Dialect division according to Tōjō

$\begin{array}{lll}4.2 & \text { Distribution of the accentuation pattern in a glottogram } & 74\end{array}$

$\begin{array}{lll}4.3 & \text { Geographical and age differences in a glottogram } & 75\end{array}$

$\begin{array}{lll}5.1 & \text { Linguistic change due to linguistic contact } & 79\end{array}$

5.2 Stages of koine development 80

11.1 Language transmission on Ikema Island 171 


\section{TABLES}

3.1 Four speaker groups and their language repertoire

3.2 Periods of language education in Okinawa Prefecture

3.3 Te-oku imperfective aspect in Okinawan-substrate Japanese

4.1 Sound correspondence between Tokyo Japanese and Shuri-Okinawan

4.2 Varieties of style in present-day spoken Japanese

5.1 Patterns of dialect contact due to relocation

25.1 Comparing multilingual and disability-oriented language rights

28.1 Youth language and Shuri-Okinawan 


\section{CONTRIBUTORS}

Shin Abe is Associate Professor at the Institute of Japan Studies at Tokyo University of Foreign Studies (TUFS). Before joining TUFS, he taught at Nagoya University of Foreign Studies (NUFS), and at Universidad Autónoma de Madrid (UAM) as a visiting professor. His recent research interests focus on sociolinguistic analysis by text mining and Japanese language education to speakers of other languages (writing assessment, pronunciation teaching and language learning/teaching beliefs). A recently published textbook for writing in Japanese is Guddo raitingu e no pasupōto (A Passport for Good Writing, with Mari Tanaka, 2014). Recently co-authored books in Japanese include Tekisuto mainingu ni yoru gengo kenky $\bar{u}$ (Linguistic Research by Text Mining, edited with Shinsuke Kishie and Satoshi Tabata, 2014), and "Hyōka" o motte machi ni deyō (Let's Go out to Town with "Evaluation", edited by Yo Usami, 2016).

Mark Anderson teaches at the University of New South Wales in Sydney. He became involved in Applied Linguistics and TESOL after emigrating to Australia from his native UK in 2000. His research interests have focused on sociolinguistic aspects of language shift since his $\mathrm{PhD}$ thesis Emergent Language Shift in Okinawa, Department of Japanese Studies, University of Sydney, 2009. Recent publications include Language Crisis in the Ryukyus (edited with Patrick Heinrich, 2014) and "Substrate-influenced Japanese and Code-switching" in the Handbook of the Ryukyuan Languages (edited by Patrick Heinrich, Shinsho Miyara and Michinori Shimoji, 2015).

Peter Backhaus is Professor at Waseda University, Tokyo. Major publications include Linguistic Landscapes: A Comparative Study of Urban Multilingualism in Tokyo (Multilingual Matters, 2007), Nihon no gengo keikan (Japan's Linguistic Landscape, edited with Hiroshi Shoji and Florian Coulmas, 2009), Communication in Elderly Care: Cross-cultural Perspectives (2013), and Care Communication: Making a Home in a Japanese Eldercare Facility (Routledge, 2017). He also regularly writes articles on Japanese language and society for the Japan Times.

Sachiyo Fujita-Round is Visiting Associate Professor at International Christian University in Tokyo. Before joining in ICU, she taught at the Faculty of Intercultural Communication at Rikkyo University Graduate School. Her present research interests focus on sociolinguistics, applied linguistics and intercultural communication, particularly in relation to speakers in multilingual/bilingual education domains. Her latest joint paper is with John Maher entitled 
"Language Policy and Education in Japan" in the Encyclopedia of Language and Education (edited by Stephen May, 2017). She has also published a chapter entitled "Japanese Language Education Policy from the Point of View of an Endangered Language Community: The Miyako Island Experience" (2016). As one outcome of her research she is currently collaborating with a video artist on a video documentary on Miyakoan bilingualism.

Mika Fukazawa is Assistant Curator at National Ainu Museum and a Researcher at the Foundation for Ainu Culture since October 2017. She graduated from Chiba University and has been awarded the Outstanding Excellence Award by Chiba University of the academic year 2016. After graduating, she worked at Sapporo Gakuin University as a JSPS Postdoctoral Research Fellow. Her present research interests focus on geolinguistics, philology and Ainu studies. Her PhD thesis is Kagake monjo ni okeru ainugo no bunkengakuteki kenkȳu (The Philological Study of the Ainu Language in the Kaga Family Archive, Chiba University, 2017), which is about the Ainu language around the nineteenth century in eastern Hokkaido.

Patrick Heinrich is Associate Professor at the Department of Asian and Mediterranean African Studies at Ca' Foscari University in Venice. Before joining Ca' Foscari he taught at universities in Germany (Duisburg-Essen University) and Japan (Dokkyo University). His present research interests focus on sociolinguistics and Japanese studies. Recently edited books in English include Being Young in Super-aging Japan (with Christian Galan, Routledge, 2018), Urban Sociolinguistics (with Dick Smakman, Routledge, 2017), Globalising Sociolinguistics (with Dick Smakman, Routledge, 2015) and the Handbook of the Ryukyuan Languages (with Shinsho Miyara and Michinori Shimoji, 2015). His latest monograph is The Making of Monolingual Japan (2012). He has been awarded the annual research award by the Japanese Association of the Sociolinguistic Sciences in 2010 and is since 2014 an honorary member of the Foundation for Endangered Languages.

Masahide Ishihara is Professor at the Global Languages and Cultures Program, Faculty of International and Regional Studies at the University of the Ryukyus in Okinawa. His present research interests focus on revitalization of the Ryukyuan languages and linguistic human rights in Japan and the US. He edited books in English, including Self-determinable Development of Small Islands (with Ei'ichi Hoshino and Yoko Fujita, Springer, 2016). He also edited books in Japanese, including Okinawa-Hawai kontakutozōn to shiteno tōsho (Okinawa-Hawai'i: Islands as Contact Zones, with Ikue Kina and Shin Yamashiro, 2010). His recent papers published in English include "Language Vitality and Endangerment in the Ryukyus" in Language Crisis in the Ryukyus (edited by Mark Anderson and Patrick Heinrich, 2014) and together with Patrick Heinrich, "Ryukyuan Languages in Japan" in Heritage Language Policies around the World (edited by Corinne A. Seals and Sheena Shah, Routledge, 2018).

Goro Christoph Kimura is Professor at the Faculty of Foreign Studies, Sophia University in Tokyo. He specializes in sociolinguistics, especially focusing on the revival and revitalization of minority languages, interlingual communication as well as the social functions of second and foreign languages. Recently he co-edited Tagengo-shugi shakai ni mukete (Towards a Multilingual Society, with Fumiya Hirataka, 2017). His latest monograph is Setsuei no susume (Setsusei: An Encouragement to be Frugal with English, 2016). Recent articles in edited books include "Gengo ni okeru shizen to jin'i" ("Naturality and Artificiality in Language"), "Eigo to genpatsu" ("English and Nuclear Power in Japan") in Kōdō suru shakai gengogaku (Engaged Sociolinguistics, edited by Hidenori Kadoya and Hideo Masiko, Sangensha, 2017), "Alternative Interlingual Strategies for 


\section{Contributors}

Crossing Linguistic Borders: Theoretical Possibilities and their Realization at the GermanPolish Border" in Language Contact and Language Policies Across Borders (edited by Barbara A. Jańczak, 2018).

Ryuko Kubota is Professor at the Department of Language and Literacy Education at the Faculty of Education at the University of British Columbia, Canada. She is a teacher educator in second/ foreign languages and a specialist of Japanese-as-a-foreign language. She has previously taught at the University of North Carolina at Chapel Hill and elsewhere in North America and in Japan. Her research draws on critical applied linguistics, critical multiculturalism, critical race theory and critical pedagogy. She is a co-editor of Race, Culture, and Identities in Second Language: Exploring Critically Engaged Practice (with Angel Lin, Routledge, 2009) and Demystifying Career Paths after Graduate School: A Guide for Second Language Professionals in Higher Education (with Yilin Sun, 2012). She has also published articles in academic journals, such as Journal of Second Language Writing, Canadian Modern Language Review, Critical Inquiry in Language Studies, International Journal of Bilingualism and Bilingual Education, Journal of Multilingual and Multicultural Development, L2 Journal, Linguistics and Education, Modern Language Journal, TESOL Quarterly, Written Communication and World Englishes. She has been actively involved in the American Association for Applied Linguistics, the International Society for Language Studies and the Teachers of English to Speakers of Other Languages.

Riikka Länsisalmi is Senior Lecturer in Japanese and Adjunct Professor in Japanese Studies at the Department of Languages at the University of Helsinki, Finland. Before returning to her Alma Mater, the University of Helsinki, she worked for a number of years as Senior Lecturer of Japanese at Leiden University, the Netherlands. Her present research and teaching activities cover a wide range of topics pertaining to the Japanese language in and outside Japan, including language (education) policies, multilingualization, language endangerment and revitalization, discourse analysis, translation and JFL pedagogy.

John C. Maher is an Irish-British Professor of Linguistics at International Christian University, Tokyo, formerly Lecturer in Japanese Studies, University of Edinburgh, and Senior Academic Member at St. Antony's College, Oxford. He holds degrees in philosophy, theology and linguistics from the Universities of London, Michigan and Edinburgh and has published over 100 articles in journals such as the International Journal of the Sociology of Language, Japanese Journal of Psychoanalysis, Translation, Applied Linguistics, Multilingual and Multicultural Development. He comments on language issues for the $\mathrm{BBC}$ and $\mathrm{ABC}$. He is the author or co-author of Nihon no bairingarizumu (Japan's Bilingualism, 1991), Gengo to bunka no tayōsei (Diversity in Language and Culture, 1994), Language and Diversity in Japan (1994), Multilingual Japan (1995), Introducing Chomsky (2001), Minority Language Revitalization (2017) and Multilingualism (2017). He was interpreter for the Ainu delegation at the United Nations'Working Committee on Indigenous Peoples. He is a founding member of the Japanese Association of Sociolinguistics.

Hidenori Masiko is Professor at Chukyo University in Nagoya, Japan. His fields of research include sociology and Japanese Studies. He has written many books in Japanese. In English the following chapters and papers are available in translation: "Life on the Small Screen: Japan's Digital Natives" in BeingYoung in Super-aging Japan: Formative Events and Cultural Reactions (edited by Patrick Heinrich and [Christian Galan, Routledge, 2018), "Japanese Sociolinguistics: A Critical Review and Outlook" in the journal Contemporary Japan (2015), and "The Politics of the Movement to Enforce Standard Japanese under the US Occupation" in Language Crisis in the Ryukyus (edited by Mark Anderson and Patrick Heinrich, 2014). 
Kazuko Matsumoto is Associate Professor at the University of Tokyo. Her main interests are language variation and change. Grounded in the variationist sociolinguistic paradigm, she has been investigating dialect contact and koineization, new dialect formation, dialect acquisition and dialect obsolescence (e.g., Japanese dialect contact and obsolescence in Palau and Peru). Her interests also include contact linguistics, e.g., language maintenance and shift (in postcolonial multilingual Palau and Japanese-Mexican migrant communities in Mexico City), contactinduced borrowing (loanwords in Palauan), nativization of newly emerging varieties of colonial languages (Palauan English) and ethnolect formation in multicultural immigrant communities (Japanese Latino immigrant communities in Japan). She has received the tenth Japanese Society for Oceanic Studies Award and was a member of the editorial board of the Japanese Journal of Language in Society.

Katsuyuki Miyahira is Professor of communication studies at the University of the Ryukyus, Okinawa, Japan. He specializes in ethnographic sociolinguistics and interactional linguistics. His latest research topic includes linguistic landscaping and translanguaging in the everyday life of heritage language speakers in Okinawa and in Okinawan diaspora communities.

Takeshi Nakashima teaches at the Department of Junior High at Prefectural Chuo School for the Deaf in Osaka and is a visiting researcher at the Sign Language Research Center at Kwansei Gakuin University. He is a CODA (Children of Deaf Adults). He is the chief editor of the academic journal of the Research Society of the Education for the Deaf in Japan. His current research interests focus on sociolinguistics, educational sociology and disability studies. He is the recipient of the sixteenth award for research presentation by the Japanese Association of the Sociolinguistic Sciences.

Yukiko Nishimura is Professor at the Faculty of Global Communications at Toyo Gakuen University, Tokyo. Her research interests include the pragmatics of CMC, specifically humor and impoliteness, and more recently emoji in social media. Her articles have been published in Journal of Computer-Mediated Communication,LLanguae@Interent, AAAI Artificial Intelligence of Humor and Journal of Politeness Research. She also has published chapters in The Multilingual Internet: Language, Culture, and Communication Online (2007) and Digital Discourse: Language in the New Media (2011), both from Oxford University Press; Across the Line of Speech and Writing Variation (2013) (from Presses universitaires de Louvain), The Routledge Handbook of Language and Digital Communication (2015) and Social Media Discourse, (Dis)identifications and Diversities (2016) (also from Routledge).

Yasuko Obana is Professor at Kwansei Gakuin University in Japan, teaching English to students in science. Her research area is pragmatics ranging from (im)politeness, anaphora in text processing to formulaic expressions as well as conversation analysis. She started her career at the University of Queensland, Australia, teaching Japanese and linguistics. This experience allowed her to complete her first book entitled Understanding Japanese (2000), which answers learners' questions and explains why they err. She is currently working on terms of address in interaction and honorifics in irony and sarcasm.

Yumiko Ohara is Associate Professor in Ka Haka 'Ula o Ke'elikōlani, College of Hawaiian Language, at the University of Hawai'i in Hilo. The college is known for its successful revitalization of the indigenous language of the region and is a part of the education system that offers education through the Hawaiian language from pre-school to the doctoral level. The 


\section{Contributors}

$\mathrm{PhD}$ degree is the first such degree in an indigenous language in the US and the first to focus on indigenous language revitalization worldwide. At the college, she teaches courses in pragmatics, gender and language, and critical applied linguistics. Her recent publications include "On Restoring Okinawan Language Transmission: What Can we Learn from the Case

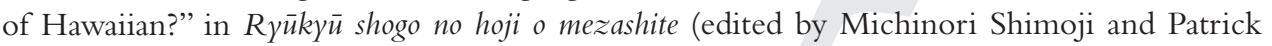
Heinrich, 2014), and "Re-inventing Hawaiian Identity: Conception of Ethnicity and Language in the Language Revitalization Movement" in the journal Internationales Asien Forum (2016).

Takayuki Okazaki is Associate Professor at Kindai University. His areas of interest include indigenous-led education, language revitalization and multicultural education. He also serves as Secretary of the Aotearoa Ainumosir Exchange Program.

Ruriko Otomo is Assistant Professor at the Research Faculty of Media and Communication at Hokkaido University. She received her PhD from the University of Hong Kong in 2017. Her $\mathrm{PhD}$ dissertation sat at the intersection between migration and various manifestations of language issues, e.g., education, assessment, and institutional communication, which examines the case of migrant healthcare workers in Japan. Her major research interests include language ideology, language policy and planning, particularly focusing on global labor mobility in the context of contemporary Japan.

Emi Otsuji is Senior Lecturer in International Studies at the University of Technology, Sydney andVisiting Research Scholar at the Institute of Asian Cultural Studies at International Christian University, Tokyo. Her research interests include language and globalization (metrolingualism and multilingualism), performativity theory of language and identities and language citizenship education. She is co-author with Alastair Pennycook of Metrolingualism: Language in the City (Routledge, 2015), and editor of Languages and Identities in a Transitional Japan: From Internationalization to Globalization (with Ikuko Nakane and William Armour, Routledge, 2015) and of Shiminsei keisei to kotoba no kyōiku (Constructing Citizenship and Language Education, with Hideo Hosokawa and Marcella Mariotti, 2016). Metrolingualism: Language and the City was chosen as a finalist in the monograph category of both the 2018 American Association for Applied Linguistics Book Award and for the 2017 British Association of Applied Linguistics Book Prize.

Shinji Sanada taught at the Department of the Graduate School of Letters at Osaka University until 2009 and is currently Professor Emeritus there. His research interests focus on varieties and styles in spoken Japanese. He is one of the early researchers who worked on case studies of contact linguistics in Japan. In particular, he captured the changes in Japanese dialects and proposed a new concept called "neo-dialect", a new inter-speech style in a community. In addition, he has been engaged in research on the remnants of the Japanese language in regions of the Asia-Pacific that were Japanese colonies until the end of WWII. In the process, he discovered Japanese-lexicon creole in Yilan County in eastern Taiwan, which is the first language of indigenous Atayal and Seediq people. The language is named Yilan Creole. He is currently conducting research on Yilan Creole with Yuehchen Chien from National Dong Hwa University in Taiwan.

Hiroshi Shoji is Emeritus Professor at National Museum of Ethnology, Osaka, where he was in charge of research and museum activities concerning linguistic and cultural affairs of Europe and Japan until 2015. He also taught at the School of Cultural and Social Studies of the Graduate 
University for Advanced Studies. His recent research themes include minority and immigrant languages and multilingual phenomena in Japan and Northern Europe. In 2004, he organized a special exhibition - "Multiethnic Japan - Life and History of Immigrants" - at the National Museum of Ethnology, a part of which is inherited in the permanent exhibition there. His edited books in Japanese include Dictionary of the World's Characteristics (2015), Immigrants, Local Communities and the States: Transitions in Asia and Europe (National Museum of Ethnology, 2009), Linguistic Landscapes in Japan (with Peter Backhaus and Florian Coulmas, 2009) and Japan: A Multilingual Society (with Shinji Sanada, 2005).

Gijs van der Lubbe is a postdoctoral research associate at the University of the Ryukyus in Okinawa. His research interests focus on the grammatical description of Ryukyuan languages and the development of learning materials, especially for the northern Ryukyuan languages. $\mathrm{He}$ is currently doing fieldwork on Okinoerabu Ryukyuan, Torishima Ryukyuan and several varieties of Okinawan Ryukyuan such as Janadō on Kumejima, Sobe in Yomitan and Sokei in Ginoza. Recent publications include "Okinawago Kumejima Janadō-hōgen no tensu asupekuto evidensharitī keishiki" ("Tense, Aspect and Evidential Forms in Kumejima Janadō Okinawan") in the journal Ry $\bar{u} k y \bar{u}$ no hoggen (2018) and, with Akiko Tokunaga, "Okinoerabu Ryukyuan" in the Handbook of the Ryukyuan Languages (edited by Patrick Heinrich, Shinsho Miyara and Michinori Shimoji, 2015). He is currently involved in various activities promoting the revitalization of Ryukyuan languages, amongst others, giving Okinawan courses for beginners and for advanced levels, the creation of learning materials and the hosting of a radio show entirely in Okinawan on a local radio station.

Zi Wang is a postdoctoral research associate at the Institute of East Asian Studies, University of Duisburg-Essen, Germany. He has degrees from the Universities of Waseda (BA) in Japan, Sciences Po Paris (MA) in France and Duisburg-Essen (Dr. phil) in Germany. He has extensive experience of conducting fieldwork on language and social relations in Tokyo, particularly in educational contexts. He has held visiting research fellowships at EHESS (Paris), Ca' Foscari University (Venice), Waseda University (Tokyo), as well as the National Institute for Japanese Language and Linguistics (Tokyo).

Rika Yamashita is Lecturer at Kanto Gakuin University in Yokohama, Japan. Her research interests include multilingualism, contact linguistics, language ideologies and language variation. Apart from her monograph Zainichi pakisutanjin jidō no tagengo shiyō (Multilingualism of Pakistani Children in Japan, Hitsuji Shobō, 2016), she has published articles and book chapters in Japanese and in English, including in the Meikai gengogaku jiten (The Sanseido Dictionary of Linguistics, 2015) and in Urban Sociolinguistics (with Patrick Heinrich, Routledge, 2017). She has been awarded the annual research award by the Japanese Association of the Sociolinguistic Sciences in 2016.

Toshiaki Yasuda is Professor at the Graduate School of Language and Society at Hitotsubashi University. He received a PhD from the Graduate School of Arts and Sciences at the University of Tokyo and previously also held a position at Institute for Research in Humanities at Kyoto University. He specializes in the history of Japanese language. His recent works include Kanji haishi no shisosshi (History of Thought on the Abolition of kanji, 2016), Jisho no seijigaku - kotoba no kihan to wa nani-ka (Political Studies on Dictionaries: What is Linguistic Prescripion?, 2006), "Kokugo" no kindaishi - teikoku nihon no gokugo gakushatachi (Modern History of "National Language": Imperial Japan and the Scholars of National Language, 2016). 


\section{ACKNOWLEDGEMENTS}

Japanese sociolinguistics has, since its inception more than 50 years ago, suffered from the absence of a comprehensive overview of the field, both in Japanese and in English. The chance to edit a handbook of Japanese sociolinguistics fills a long-standing gap, and we are very grateful for having had the opportunity to do so. As educators teaching Japanese sociolinguistics, we are also happy to now have a book at hand that will hopefully prove helpful for many students of Japanese sociolinguistics. We also hope that it will inform students of sociolinguistics specializing in other languages, too. We seek to update readers how different Japan is from the stereotypical but inept view of a monolingual and socially homogenous society. The handbook presents Japan as a multilingual and diversifying society, reflecting a trend that has by now become mainstream among specialists.

There is diversity between the authors assembled in this book, too. The handbook brings together scholars of critical sociolinguistics, Japanese sociolinguistics that developed from the expansion of Japanese dialectology and language life studies, but also scholars who were trained outside of Japan and who have applied ideas and concepts developed in other countries on Japanese cases and examples. Each and every one of these traditions provides for important insights, and we spent most of our time as editors ensuring that all these directions in Japanese sociolinguistics are equally well represented in this volume. We made great efforts to put these various works into perspective, and we hope that we have succeeded in this.

We are grateful to all authors assembled in this book for taking the time to write a chapter and share their expertise with us and our readers. Working with everybody has been a pleasant and enriching experience. A number of colleagues have also helped us in editing chapters. We are grateful for the assistance of Goro Christoph Kimura, Riikka Länsisalmi, Kazuko Matsumoto and Yuko Sugita. A special thanks goes out to Mark Anderson for helping to systematize the grammatical annotations in this book. At Routledge, everybody has been extremely supportive from the start, and we also greatly appreciate their patience, as we had to push back the deadline for submission of the manuscript a couple of times. As editors of a book on Japanese sociolinguistics, we are aware that we are following in the footsteps of many great scholars from whom we have ourselves learned so much. Due to their work, research on Japanese sociolinguistics is today "at home" both in and outside of Japan. We are dedicating this handbook to three scholars of Japanese sociolinguistics who have exemplified how to present research on Japanese sociolinguistics that stands the test of time, because it exemplifies something on the 
example of Japan that is insightful for sociolinguists around the world. This book is dedicated to Jiř́ Neustupný, Orie Endo and Katsue Akiba-Reynolds.

Jiří Neustupný had studied with such different scholars as Roman Jakobson, Tokieda Motoki and Hattori Shirō in the 1960s, and he had a crucial impact on the formation and development of sociolinguisticcs in Japan. Patrick vividly remembers his disappointment and his words for all studies that he saw as being too narrowly concerned with the case of Japan only, but also with studies that failed to properly understand Japanese language and society. He always sought and encouraged his students to grasp "what is really going on". When one traces Orie Endo's accumulative work since 1970s, it becomes obvious that it paved the way for the current stream of research examining the ideological nature of "women's speech" in Japanese. By challenging common-sense assumptions about language and language use through the analysis of dictionaries, historical documents and lexical innovation by comtemporary young women, Endo was able to elucidate the differences between language ideologies and actual descriptions of language. This marks a crucial leap in the field. Katsue Akiba-Reynolds demonstrated that many supposedly "recent" changes in language have been with us for a long period of time. At the same time, what are seen as sociolinguistic "restrictions" on certain personal pronouns, grammatical structures, final particles and the ensuing consequences when breaking those restrictions only make sense when juxtaposed with ideological notions of Japanese. As a researcher as well as a professor, Akiba-Reynolds advocates a critical stance where one never ceases to question one's own assumptions.Yumiko, who has studied with her, has very much benefitted from this important lesson and feels forever grateful for this.

All in all, we truly hope that this book captures some of the originality, thoroughness and intellectual curiosity of these three scholars. May students of Japanese sociolinguistics around the world find this handbook helpful in their very own way and in their own novel attempt to capture, deepen or expand our knowledge of Japanese language and society.

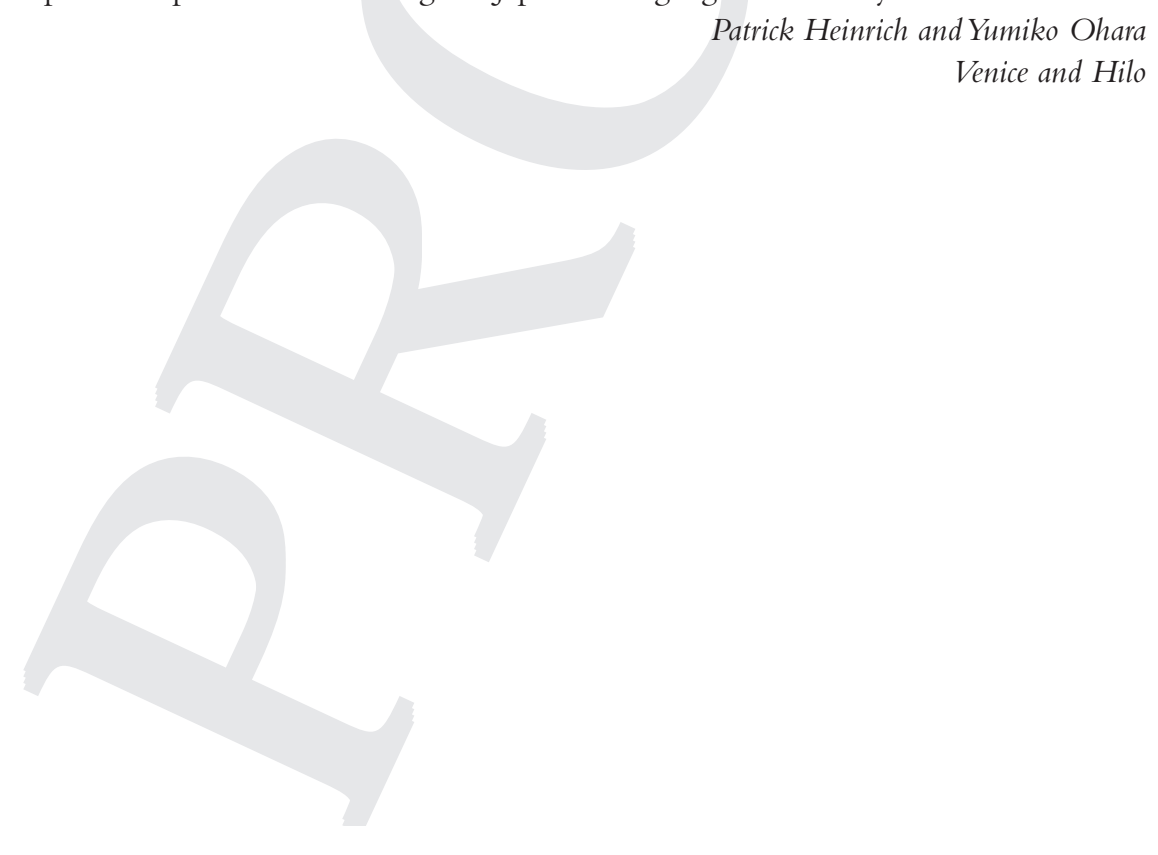




\section{CONVENTIONS}

Some brief words on conventions. Japanese terms in the text are transcribed in the modified Hepburn system. Japanese personal names are a problem. Their usual order is of course that of family name first. At the same time, a great number of Japanese scholars are very active outside Japan and treating their names as "foreign" there by keeping the Japanese order and putting macrons on long vowels unduly marks them as "outsiders". There is no solution to this that will make everyone happy and do justice to all. We chose to use the first-name family-name order for our authors in this book and for all those who are well known outside Japan in contemporary scholarship, but we kept the traditional order for other Japanese nationals. We should however add that Goro Kimura Christoph and Masiko Hidenori prefer to have the Japanese order. On the other hand, we follow the preferred transcriptions of personal names by Japanese, using thus Masiko instead of Mashiko or Sibata Takesi (instead of Shibata Takeshi). We live in a postmodern world, and we can deal with some ambiguity. Long vowels in Japanese are represented with a macron, e.g., Jōmon period. Long vowels in Ryukyuan languages are instead represented by double vowels, e.g., uchinaa. We refrained from marking the long vowels in all Japanese places as many of them are widely used in English, that is, we treat words like Ryukyu, Hokkaido, Tokyo, Kyoto or Osaka as English words. Many chapters make reference to the Japanese periodization of history. The most frequently used are the following: Edo Period (1603-1868), Meiji Period (1868-1912), Taishō Period (1912-1926), Shōwa Period (19261989) and Heisei Period (1989-2019).

This leaves us with grammatical annotations. We are grateful to Mark Anderson for having assisted us on this thorny issue. Below, the conventions we use in this handbook:

$\begin{array}{ll}1 & \text { first person } \\ 2 & \text { second person } \\ 3 & \text { third person } \\ 4 & \text { fourth person } \\ = & \text { clitic boundary } \\ \varnothing & \text { bare case marking } \\ \text { A } & \text { transitive subject or possessor } \\ \text { ABL } & \text { ablative } \\ \text { ACC } & \text { accusative }\end{array}$




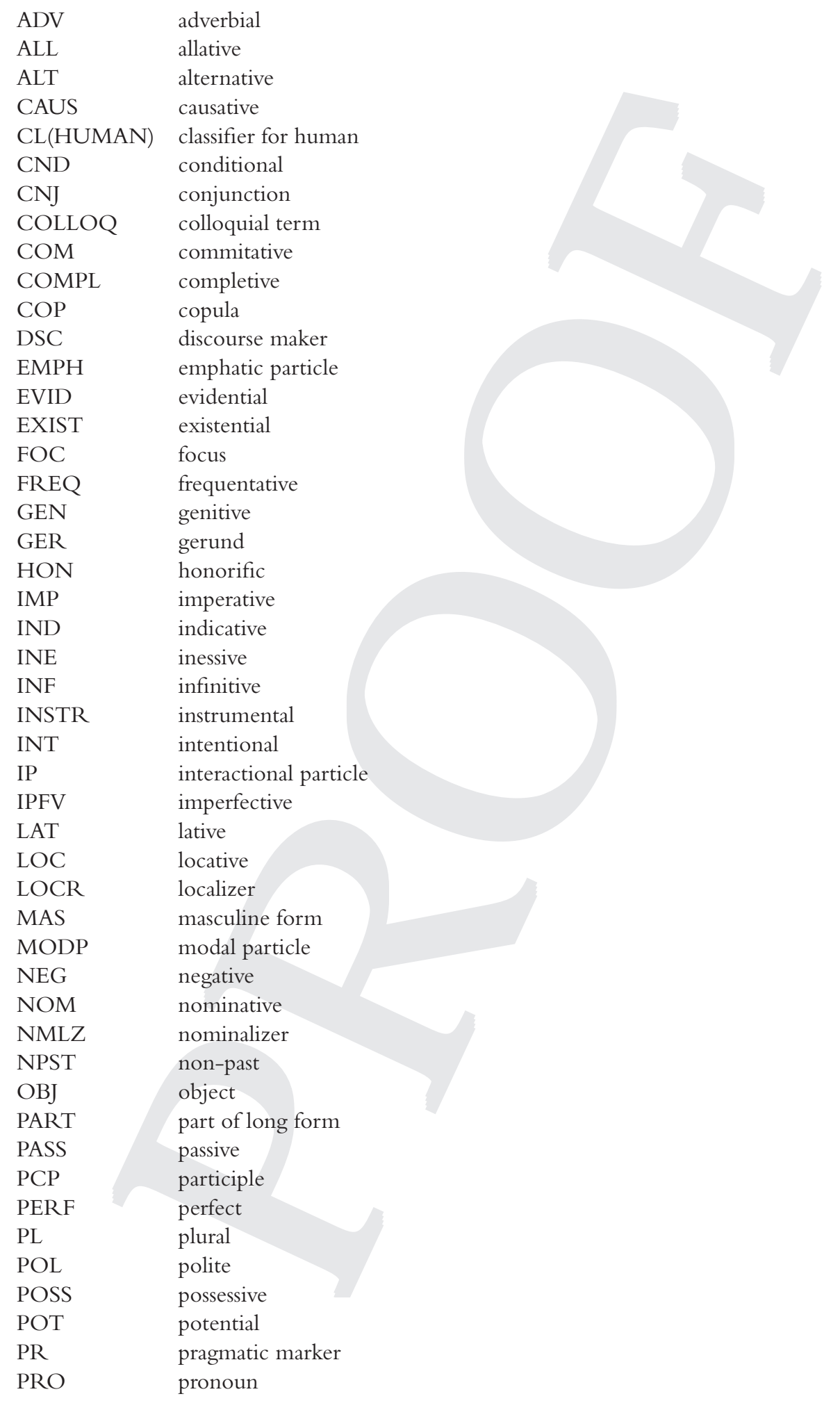




\section{Conventions}

$\begin{array}{ll}\text { PROG } & \text { progressive } \\ \text { PST } & \text { past } \\ \text { PURP } & \text { purposive } \\ \text { Q } & \text { question/interrogative marker } \\ \text { QT } & \text { quotative particle } \\ \text { RECP } & \text { reciprocal } \\ \text { RES } & \text { resultative } \\ \text { S } & \text { intransitive subject } \\ \text { SEQ } & \text { sequential } \\ \text { SFP } & \text { sentence-final particle } \\ \text { SG } & \text { singular } \\ \text { TOP } & \text { topic marker } \\ \text { VOL } & \text { volitional } \\ \text { VULGAR } & \text { vulgar form } \\ \text { WHQ } & \text { wh-question }\end{array}$

